\title{
Tatyana Bozhko
}

Kyiv National University of Trade and Economics

e-mail: tatyana_bozhko@ukr.net

\section{CONSUMER PREFERENCES ON THE UKRAINIAN MARKET OF LIQUEURS. THE REVIEW}

\begin{abstract}
Summary: The aim of the paper is to analyze the market of alcoholic beverages in Ukraine and to identify the directions of expanding the range of these products by developing new recipes of enriched mix drinks (with fitoletsytyne, chicory and skimmed milk). The article presents the classification of liqueur drinks in Ukraine. It highlights the role of the quality of raw materials used for the production of liqueurs in Ukraine nowadays. Great attention was also paid to the study of consumer preferences on liqueurs segment.
\end{abstract}

Keywords: liqueur, commodity classification of liqueur-vodka products, consumer preferences.

DOI: $10.15611 /$ nit.2014.2.02

\section{Introduction}

In many countries of the world the consumption of alcohol, as a means of satisfying some human necessities, shows by itself the inalienable element of life and culture of the major part of population and it is perceived in mass consciousness as the socially acceptable phenomenon. The consumption of alcohol also serves to meet some psychological functions (helps relax, takes off tension, calms down, brings pleasure). Its social functions are also very important [Tapilina 2006]. The consumption of alcohol is a social action which is executed by a man with friends, family, colleagues, command; assists socialization (communication, forming of public and individual connections, expression of trust, hospitality and goodwill) and also is the attribute of celebration of important events in the peoples' life [http://ife.obozrevatel.com/ consumer/73926-navodka-na-vodku.-istoriya-v-detalyah.htm; Tamberg, Badin 2014].

It is important to have in mind that prolonged and excessive drinking leads to the creation of the alcohol dependence and results in the higher risk of incidence of diseases specifically associated with it (alcoholic psychosis, alcohol dependence or alcohol poisoning) as well as it may contribute to the formation of many other diseases and health problems and to increase the risk of their appearance [Szkody zwiazane... 2014; Lasarew 2014]. Long-term and excessive drinking of alcohol 
leads to the creation of the alcohol dependence and results in higher risk morbidity specifically related to it: alcoholic psychoses, dependence on alcohol and alcohol poisoning, as they may contribute to the formation of many other diseases and health problems and increase their risk [Global status... 2014].

The real liquor (but not the forgery of sophisticated chemical substitutes imitating various natural flavors, fragrances, dyes, which are mainly used for domestic and foreign production of alcoholic beverages) may be made only with natural flavors and essences (for example, natural essential oil). Cream liqueurs are currently enjoying the highest demand on the world market compared to other beverages. The name of this product usually begins with the words "Creme de...". The class of cream liqueurs is not too large. A characteristic feature is its dense structure (due to the high sugar content - up to $60 \%$ ). For the preparation of creams enriched fruit drinks, juice and infusions, preserved juice by sugar, and natural essential oils are used. Scientists from the Kyiv National University of Trade and Economics (KNUTE) have developed new types of cream liqueurs of the desired organoleptic properties that can be used in food for better health. This project was carried out as follows: to drinks, in addition to the traditional raw materials (sugar syrup and egg yolks) the 'Tsykorlakt' was added (a dry blend of chicory extract and skim milk) and fitoletsytyne. Moreover, in one of the new liqueurs instead of spirits 'Ciluszczy' lotion was used (with the power of the finished drink (about $20 \% \mathrm{v} / \mathrm{v}$ ), which is the enriched product.

The aim of the paper is to analyze the market of alcoholic beverages in Ukraine and to study the consumer preferences of liqueurs segment.

\section{Commodity classification of liqueurs}

The commodity group of liqueur-vodka products in Ukraine includes alcoholic beverages with different amount of alcohol, sugar and various aromatic and taste properties, by the conditioned types of fruit and aromatic or nonaromatic raw materials used for their preparation.

There are eight groups of liqueur-vodka products. Indexes of chemical composition, organoleptic indexes and physiology action of drinks to the human organism are taken as the basis for classification of liqueurs (Table 1).

Emulsive (creams) liqueur's consistency has to be homogeneous; a color is brightly expressed, characteristic for a kind and brand of a product. Other liqueurs have to be transparent without the extraneous included. The formation of turbid drop is possible by overthrowing the bottle and its disappearance is assumed while shaking the bottle.

The name of a drink usually specifies the type of the basic raw material used for this product (strawberry, cherry liqueur) or is related to the local name, where it was made ("Old Tallin", "Riga" balsam, "Kursk White Tinctures" liqueur and others). Sometimes the name specifies the way of preparation. For example, "Crystal" liqueur differs in that the crystals of saccharine appear on walls and bottom of the bottle. 
Table 1. Ukrainian classification of liqueur-vodka products

Tabela 1. Klasyfikacja ukraińskich likierów

\begin{tabular}{|l|c|c|c|}
\hline \multirow{2}{*}{$\begin{array}{c}\text { Group of liqueur-vodka } \\
\text { products }\end{array}$} & \multirow{2}{*}{$\begin{array}{c}\text { Alc., } \\
\% \text { vol. }\end{array}$} & \multicolumn{2}{c|}{ Mass concentration, g/100 $\mathrm{cm}^{3}$} \\
\cline { 3 - 4 } & & general extract & acids, in a count on citric acid \\
\hline Liqueurs & $25,0-45,0$ & $25,0-60,0$ & $0-0,8$ \\
\hline (emulsive liqueurs) & $(18,0-25,0)$ & $(15,0-45,0)$ & $(0-0,2)$ \\
\hline Nalyvky & $15,0-35,0$ & $15,0-50,0$ & $0,2-1,3$ \\
\hline Tinctures & $20,0-60,0$ & $0-20,0$ & $0-1,0$ \\
\hline Balsams & $35,0-45,0$ & $7,0-30,0$ & - \\
\hline Aperitifs & $15,0-30,0$ & $5,0-20,0$ & $0,2-0,7$ \\
\hline Cocktails & $20,0-40,0$ & $5,0-25,0$ & $0-0,5$ \\
\hline Dessert beverages & $12,0-15,0$ & $15,0-30,0$ & $0,2-1,0$ \\
\hline Low-alcohol beverages & $1,2-8,5$ & $3,0-14,0$ & $0,1-1,0$ \\
\hline
\end{tabular}

Source: [ДСТУ 4256... 2003].

Źródło: standard ukraiński [DSTU 425... 2003].

In different countries the classification of liqueurs is not the same and depends on potency, content of sugar, technology of production or the type of raw material. It is difficult to classify liqueurs because of their variety. Generally, they could be divided into three groups: herb liqueurs - made from fruits (or fruit juice), spicy liqueurs aromatized by fruit or their parts, bitter liqueurs - whisky's type of liqueurs.

Liqueurs with fruit, coffee, herb and cacao contain no less than $25 \%$ vol. of alcohol, fruit and vanilla liqueurs contain $30 \%$ vol. of alcohol and liqueurs aromatized by fruit and liqueurs with honey - no less than $35 \%$ vol. of alcohol.

Medicinal or ordinary herbs are one of the oldest components of liqueurs. Now producers become interested in the specific smell of product, but not everyone thinks about the curative properties of liqueurs.

A lot of companies are focused on a new model of development, because they are provided for objective changes on the Ukrainian market. Nowadays, there are many attractive niches on the Ukrainian liqueur-vodka market, which, being undertaken into realization by business, can be extended. The prevalence of bitter tinctures testifies to this. Consumers preferred vodka a few years ago and it seemed that the negative attitude to other beverages did not make it possible to make a good profit in the segment of liquors. Tinctures were seen mainly as national exotic drinks (for example, "Pertsivka"). Some companies have introduced the production of bitter tinctures and it happened at the beginning of an independent group of liquors.

Formally Ukraine, as well as Russia, is attributed to the consumption of the north type alcohol. Unlike the south, where easy drinks prevail with subzero content of alcohol and sugar, it is characterized by the prevailing positions of strong sweet alcohol and beer. 
However, when it comes to Ukraine, this kind of consumption is quite distorted as pure vodka dominates, and in other countries it is often the basis for alcoholic cocktails. Beer is an alternative to vodka (which is very popular now bringing our country to the classic northern type of alcohol use) as well as strong wine (16-18\% vol. of alcohol), which poorly involves the definition of civilized market of alcoholic beverages [Ogórtsov 2014; Zamogylny 2007].

Fortified wines actually hold in our niches, in the northern consumption type called "niches of sweet alcohol". Unfortunately, a Ukrainian consumer buy more strong wine than sweet alcohol. However, tinctures and liqueurs are strong sweet alcohol, made from the Ukrainian natural resources, which perfectly enters the reasonable theories concept of "the northern type of alcohol consumption", where consumers prefer strong spirits [Rehn 2001; Tapilina 2006].

Difficult and expensive production explains why the spirits (liquor) are not common among manufacturers: the need for a careful selection of ingredients, adding extra natural oils, ready liqueur maturing for about two years (and this is different from the simple production of cheap wine). In the Soviet times the production was based on low-quality ingredients, and because of that liqueurs were not popular among consumers.

As a result the Ukrainian market has lost one of natural constituents of the north type of alcohol consumption triad (vodka - tinctures/liquors - beer) and a Ukrainian consumer's remarkable drink, i.e. tinctures/liquors, is replaced by cheap strong wine.

Traditionally in Ukraine strong alcohol was consumed not for its taste, but for intoxication. This tradition was against the world tradition of consumption. Alcohol was regarded as as a source of pleasure abroad, not just banal entertainment. That is foreigners consume alcohol mainly as a tasty drink.

Gradually European traditions of consumption of alcohol spread to Ukraine. At first, it refers to the inhabitants of megalopolises, whose queries grow together with the level of profits, and knowledge of western life and approaching to its standards becomes more complete. In addition, the young generation does not support the tradition of consumption of vodka, and gives advantage to interesting natural taste of alcohol. At the same time the level of consumption of prestige alcohol with high organoleptic properties by women grows nowadays [Zamogylny 2007].

As already mentioned, liqueur is not the most popular alcoholic beverage among domestic producers. But today, there is a visible attempt to revive and to develop a forgotten niche taking into account consumer preferences for this drink. It is manifested by the decrease of cheap products on the market being replaced by liqueurs with a clear positioning and qualitative characteristics [Lowczev 2013].

Liqueurs are the sweetest and the most pleasant drinks from all alcohol beverages. They are especially popular among women. That is why a lot of producers of Ukrainian alcoholic products aspire to extend the assortment of liqueurs.

This drink appeared in the XIII ${ }^{\text {th }}$ century due to Benedictines, who invented it. At first liqueur was used as medicine, and was made from herbs, fruit, singed sugar and 
honey. From the $\mathrm{XIX}^{\text {th }}$ century liqueur began to be used as a noble drink [http://life. obozrevatel.com/consumer/73926-navodka-na-vodku.-istoriya-v-detalyah.htm; Karagodin 1998].

Now liqueurs are often divided into two groups: drinks which are consumed in a pure form and also liqueurs as constituents of cocktails. This division is conditional and depends on individual traditions and advantages. "Clean" liqueurs successfully complement cocktail compositions and vice versa.

\section{Consumer preferences on the Ukrainian liqueurs market}

The least alcoholic kind of liqueurs are creams, which (according to studies) are most popular on the world market compared with other types of liqueurs. Its name usually begins as "Creme de...". The class of cream liqueurs is not variable; its hallmark is a thick viscous consistency due to high sugar content - up to $60 \%$. Traditionally bleach fruit drinks, infusions, bleach and sugar, canned juice, cocoa powder and chocolate are used for cooking cream [Karagodin 1998].

The most popular cream liqueurs in Europe are drinks which consist of egg yolks, sugar and cognac. In Holland, Poland and other countries a similar drink is produced with the name of Advocaat, in Italy - Cremovo. In Hungary such a liqueur is produced from quail eggs.

The creamy cream-liqueurs made by the Irish firm R.A.Bailey are a new subclass of these drinks. Baileys Cream is produced from Irish triple distilled whisky, cream, cacao, sugar and vanilla. Its alcohol content is $17 \%$ vol. and expiration date is 2 years. It is the most popular drink of this class and more than 50 million bottles are sold annually.

The Irish firm "Carolans and Son" produces liqueur which consists of Irish whisky, double natural creams, honey and chocolate. Its alcohol content is $17 \%$ vol.

The most popular brands in the world liqueurs market are: Sheridans, Cointreau, Kalhlua, Amaretto, Malibu, Limoncello di Campri, Xenta Cummel and many others. The world leaders in this product segment are Marie Brizard, De Kuyper and Bols.

At the determination of countries - producers of liqueurs which enjoy the most confidence, Ireland is an implicit leader. This country has been identified as such by more than $37 \%$ consumers (Figure 1). Italy and Great Britain have collected similar number of voices, approximately $-18,61 \%$ and $16,24 \%$ accordingly. Such countries as Holland, Ukraine, the Czech Republic and Estonia belong to the category of "other" [Gaponov 2014].

Being a part of a powerful spirit portfolio of international companies with appropriate opportunities for development, liqueurs take a very strong profitable position on the world market, as well as in retail and in the segment of bars and restaurants.

The market of liqueurs in Ukraine, such as in the whole world, is divided into two segments: off-trade (imported and Ukrainian products) and on-trade (liqueurs of 


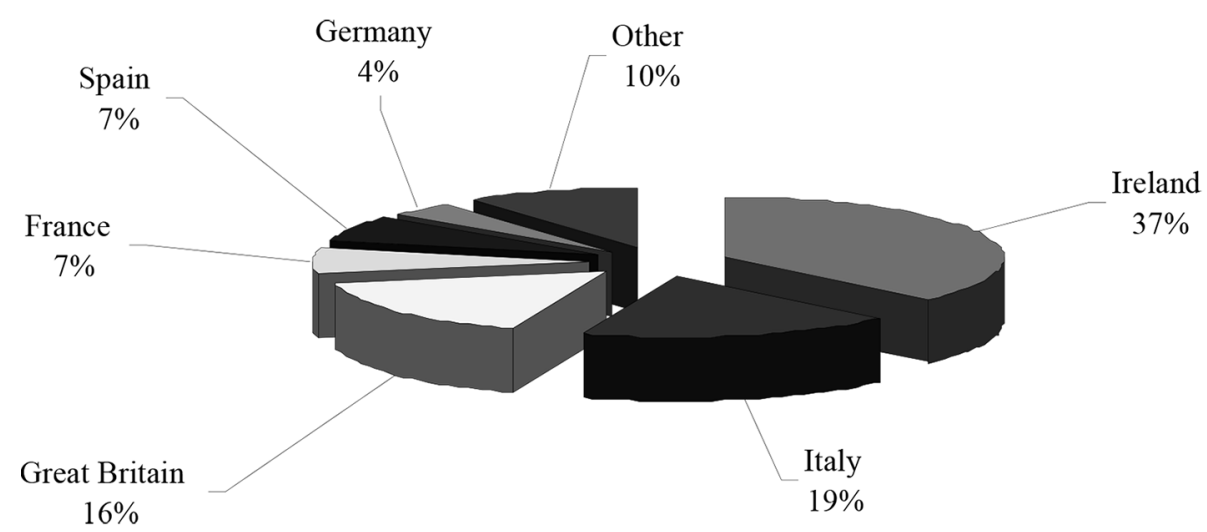

Figure 1. Consumers' selection of a country which is the best producer of liqueurs

Source: [Gaponov 2014].

Rysunek 1. Opinia konsumentów dotycząca wyboru kraju będącego jest najlepszym producentem likierów Źródło: [Gaponov 2014].

foreign production). In the first branch importers can see the prospect of increase of sales due to the popularity of liqueur brands, the stimulation of purchase, and the realization of advertising actions. In the second branch it is in the increase of professionalism of barmen and waiters, who sell cocktails.

All of this is connected both with the advancement of the known cocktail mixing and with the development of new mixes. The whole market depends more on the main constituent - the development of restaurant business (HoReCa) in the country and the increase of the amount of decent establishments. Any ambitious producer or importer of wine, vodka or cognac dreams about the maximal scope of HoReCa retail points, when a drink has such a refined image as a liqueur.

According to research results, more than $35 \%$ consumers buy liqueurs in supermarkets, and more then $30 \%$ - in entertaining establishments, such as a bar, club or restaurant (Figure 2). These indexes confirm results presented before about the consumption of liqueurs by consumers at home or in the designated places [Bondar 2014; Gaponov 2014].

Liqueur is a status drink and is not viewed as a daily treat. Thus, the assortment of liqueurs in similar retail enterprises cannot completely satisfy a gourmet.

Among products which acquire the most popularity by a Ukrainian consumer are cream-liqueurs (Bailey's, Sheridans, Carolans, Cointreau and Kalhlua), cocktail liqueurs (Marie Brizard and De Kuyper), and well known western bitters (Becherovka, Fernet Branca and Amaro Ramazzotti). Consumer opinions about the trademarks of liqueurs are given in Figure 3. 


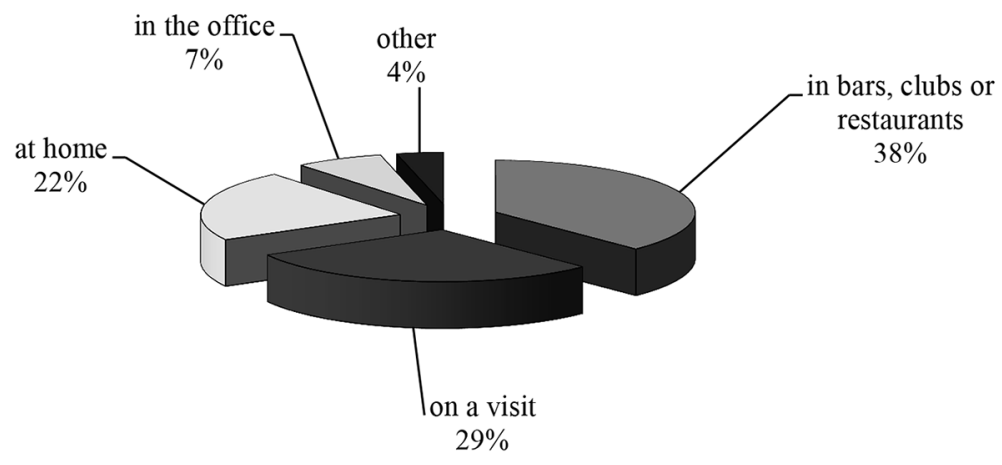

Figure 2. Consumer opinions about the places of consumption of liqueurs, in $\%$ Source: [Gaponov 2014].

Rysunek 2. Opinie konsumentów na temat miejsca konsumpcji likierów, w \% Źródło: [Gaponov 2014].

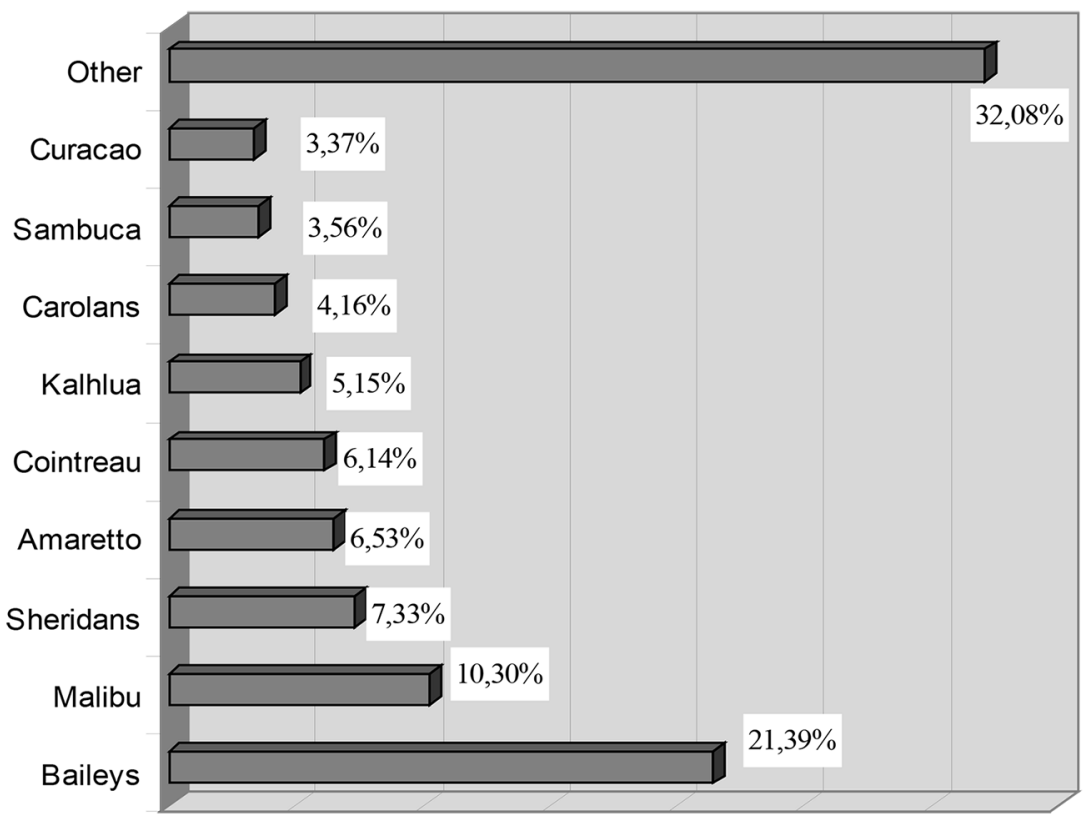

Figure 3. The popularity of liquers trademarks among consumers, in $\%$ Source: [Gaponov 2014].

Rysunek 3. Popularność marek likierów wśród konsumentów, w \% Źródło: [Gaponov 2014]. 
The most popular liqueur is Bailey's (Ireland). It is demanded by $21,39 \%$ respondents. There is even a certain stereotype in relation to this brand. If you do not know what to order, you will take Bailey's. Such an attitude testifies to the trust of consumers to this brand and to its considerable status.

The second position in the rating of the brands is occupied by Malibu liqueur (Diageo Plc., Great Britain), which was chosen by 10,30\% consumers. We can see that the popularity of the Maliby TM products is more than twice lower in comparison with the liqueur of Bailey's. In the category "other" there are also Ukrainian liqueurs produced by Lviv liqueur-vodka plant and Zolotonosha liqueur-vodka plant. These products are bought by consumers who rely only on their organoleptic features.

In the off-trade segment experts forecast the increase of competition in the class of creamy liqueurs due to the formation of new price niches. However, there may be competition among the "branded" liqueurs in HoReCa. Now a level of sales directly depends on marketing efforts of companies-sellers of liqueur brands.

We know that at different times Ukrainian liqueur-vodka plants have tried to produce sweet alcohol, but without success. It refers to low price drinks that have negatively influenced not just the registration of products but also their its highquality-taste descriptions.

Periodically some regional producers work with liqueurs. For example, Lviv liqueur-vodka plant have produced these drinks under a trademark "Володар" ("Volodar"). Now leadership of this plant changed the approach to liqueurs by renewing an assortment (apricot, cherry, coffee, lemon, and chocolate are included in taste series) and uniting all liqueurs under a trademark "Старий Ринок" ("Stary Rynok").

On the background of very high competition and saturation of alcoholic market as a whole, there is still place for liqueurs niche. However, it will not last for too long as modern tendencies have already testified to the revival of liqueurs producers. Experts forecast rapid development of strong sweet alcohol market in Russia and Ukraine soon. In the future it is bound to return to its former position, stamping "wine drinks" of different durability from the present place.

The first sign of changes is the appearance of cheap and elite products on this market. Thus, the market underwent a sharp deficit of middle-priced alcohol from local producers, who work with their own or licensed brands. We are talking about a price niche of 2-4 dollars for a tincture (bottom limit is more attractive and natural for Ukraine, overhead - for Russia), and about 8-15 dollars for classic liqueurs.

The correct price positioning is a small part of success. Drinks of this category have to be natural, in quality answering the best world analogues. The imbalance on the liqueur-vodka market can be improved if similar products of Ukrainian producers are addressed. Preconditions for a favorable reaction of consumers are that their number will "grow" steadily, they will better understand drinks for their naturalness and originality of taste, and also deficit on the market of similar suggestions and imported analogues of the same price category. 
In comparison with family markets, it is possible to mark an origin of "middle class" alcohol in post-Soviet countries, which began to experiment and give advantage to the prestige products. A few years ago we witnessed the beginning of stormy sales of cognac both in Russia and in Ukraine (in Soviet times this drink lost its position to vodka). The nature of infatuation for this product consisted in that on the background of a traditionally banal vodka, cognac really looked extraordinarily prestigious, and it appropriately resulted in the increase of its number of loyal consumers on the market.

A few years ago a low-alcoholic group began a serious competition with vodka especially in terms of taste descriptions, but not from the point of view of prestige. New generation is not ready to the consumption of "strong alcohol" and is satisfied with low-alcohol sweetish drinks. Soon producers will create premium low-alcoholic drinks, with natural tastes and high-quality alcohol. As a result low-alcoholic drinks gradually began to oust vodka and cheap fastened wine from the everyday alcoholic ration of Ukrainians.

All the above-mentioned facts testify that sweet tinctures and liqueurs, which enter the market, can fully move up on the successful way of development, like cognac and low-alcoholic drinks, using the taste preferences of consumers and status differentiation as an advantage.

The first significant attempt to work in the segment of tinctures and liqueurs in a radically new situation are 'SLÁDEK drinks shopping centers. They sell the liqueurs: "Taste of Prague" (cherry, lemon, cranberry, spicy) and classic elite liqueurs "Taste of Paris" (rose, chocolate, royal citron). These liqueurs are made exclusively from natural components and similar products are not almost present on the markets of post-Soviet countries. If in the segment of creams our consumers are already aware of advantages, choosing the best world brands, then transparent liqueurs remain the real riddle: they are rarely bought for home, rarely consumed in a pure form, in general little is known about them, and, actually, they are undeservedly underestimated. Therefore it will be necessary to break stereotypes when in fact first liqueurs, in the classic understanding of this word, appear in Ukraine. It means that all drinks are made without the use of flavors and dyes, and the basis of taste and aromatic compositions are essential oils and spirit infusions.

In support of traditional production of classic liqueurs, products are equipped with a refined packing: liqueurs are poured in the French high bottle of regular shape and the place of label is occupied by an elegant decor. A bottle is with an original cork, and is protected from imitations by thermo-assiduous transparency with the gold causing. All liqueurs are for sale in the souvenir cardboard basket (a figured cut in a forehand and a cord that reminds about the dresses of the courtly epoch of bloom of the French monarchy time when liqueurs actually appeared and became popular add the piquancy of the packing). 


\section{Conclusions}

The analysis of selected problems shows that the future of liqueurs is verypromising. Now everything depends whether producers will benefit from this opportunity or they will launch other category of alcohol (such as vodka or low-alcohol drinks) on the market.

\section{References}

Badania marketingowe wśród konsumentów napojów alkoholowych. Moskwa. Badanie konsumentów, http://www.slideshare.net/SergeyGnedkov/ss-28492716, May 2014.

Bondar M., Wódki nie bywa za dużo: co, jak i dlaczego pija nasi rodacy, http://kontrakty.ua/article/45385/, May 2014.

ДСТУ 4257, Liqueur-vodka products. Specifications, Kiev 2003.

Gaponov A., Preferencje mieszkanek Moskwy na rynku likierów, http://www.adme.ru/research/predpochteniya-moskvichek-na-rynke-likerov-25796/, May 2014.

Global status report on alcohol and health, World Health Organization 2011, http://www.who.int/substance_abuse/publications/global_alcohol_report/msbgsruprofiles.pdf, May 2014.

http://life.obozrevatel.com/consumer/73926-navodka-na-vodku.-istoriya-v-detalyah.htm, 2014.

http://www.slideshare.net/SergeyGnedkov/ss-28492716, May 2014.

Karagodin G., Book about Vodka and Winemaking, Ural LTD Publishing Company, Tcheliabinsk 1998.

Lasarew P., Alkohol i tytoń na Ukrainie. Podejście europejskie, http://inpress.ua/ru/society/22636alkogol-i-tabak-v-ukraine-evropeyskiy-podkhod, May 2014.

Lowczev V., Alkohol w kulturze europejskiej: monografia, M.: ID KDU, 2013, 548.

Ogórtsov P., Historia pótnocnego stylu konsumpcji alkoholu w Rosji, http://www.magalif.ru/?an=stat_ alco_istformir, May 2014.

Rehn N., Room R., Edwards G., Alcohol in European Region - Consumption, Harm and Policies. Report, World Health Organization, Regional Office for Europe, 2001.

Skupiając się na wódce. Historia w szczególach, http://life.obozrevatel.com/consumer/73926-navodkana-vodku.-istoriya-v-detalyah.htm, May 2014.

Szkody zwiazane z dlugotrwatym nadużywaniem alkoholu, http://www.bezpytan.pl/index-74.html, May 2014.

Tamberg V.A., Badin A., Kultura konsumpcji napojów alkoholowych, http://newbranding.ru/articles/ alco-culture, May 2014.

Tapilina V.S., How much is drinking Russia: range, dynamics and differential of using of alcohol, Case Studies, "SOCIS" 2006, vol. 2, p. 85-94.

Zamogylny D., Wspótczesne trendy na rynkach alkoholowym i bezalkoholowym w Rosji i na Ukrainie, [in:] Problemy rozvitku zovnishnoekonomichnih zv'yazkiv i zaluchennya inozemnih investitsiy: Regionalny aspekt - kolekcja prac naukowych, eds. D. Zamogilny, A. Sayapin, O. Czernych, Donetsk National University, Donieck 2007. 


\section{PREFERENCJE KONSUMENTÓW NA UKRAIŃSKIM RYNKU LIKIERÓW. PRACA PRZEGLĄDOWA}

Streszczenie: Celem pracy było przeprowadzenie analizy rynku napojów alkoholowych na Ukrainie oraz określenie kierunków poszerzenia zakresu tych produktów poprzez opracowywanie nowych receptur, tj. wzbogaconych napojów miks (z fitolecytyną, cykorią i odtłuszczonym mlekiem). W artykule przedstawiono klasyfikację likierów na Ukrainie. Podkreślono znaczenie jakości surowców wykorzystywanych aktualnie do produkcji likierów na Ukrainie. Szczególną uwagę poświęcono także badaniom preferencji konsumentów w segmencie likierów.

Słowa kluczowe: likiery, towaroznawcza klasyfikacja produktów „likiery-wódki”, preferencje konsumentów. 